\title{
Nutrition in a Healthy Way as One of the Best Ways to Fight Obesity. Negative Impact and Not Sustainable of Chemical Medilcaments
}

M. Agolli

University “Eqrem Çabej”, Gjirokastra, Albania

M. Terpo

University “Eqrem Çabej”, Gjirokastra Albania

Email:agollimaria@yahoo.com

Dh. Terpo

E.Meçi

University "Eqrem Çabej”, Gjirokastra Albania

Email: agollimaria@yahoo.com

Doi:10.5901/mjss.2014.v5n13p172

\section{Abstact}

Obesity can be defined as the presence of excess fat tissue or bodily adipoze. Many decades, obesity has become worldwide problem but the last decade is a serious concern in our country. Disturbing is the fact that it is growing rapidly among children and young people. Obesity is now epidemic that is spreading at high rates and therefore called unstoppable plans and globesity. Out of ignorance, not health information, and social inactivity he is growing rapidly and threatening. Globalization of the economy creates conditions for excessive use of inappropriate foods, especially prepared, the industrialized super concentrate with sugars, fats, alcohol and more calories overall. Traditional food products containing fibrous vegetables, fruits, milk, etc. Practically identification, information, prevention and treatment of this phenomenon leaves much to be desired. Diagnosis and treatment of obesity carries a greater economic weight and emotional. These reasons motivate us to analyze first the factors that affect these areas the problem of obesity. Highlighting some way of feeding antiobesity this article attempts to provide a modest assistance in the fight against this epidemic. Second, examination of obesity requires a new economic report. This is related to the structure, composition, processing, packaging and marketing of products and consequently between the components required to establish a new report, the impact of which constitutes simultaneously purpose of our article.

Keywords: economics, epidemics, globalization, obesity, fed

\section{Introduction}

"When it comes to nutrition must learn and learn to know how to eat to live, not live to eat"

"A. Xoxe"

To elaborate and understand better nutrition and more specifically antiobezitet is first necessary to have a clear vision of what is obesity.

Obesity referred to as "syndrome X" is now a worldwide problem with an extension of the largest ever across the globe as the most identified as the disease of the century or "globezitet". Most authors think that IF is not taken preventive measures are passing millennium that threatens to turn into an age of obesity.

For the historical character mentioned by Hippocrates as early obesity century. V BC when stating that "the sudden death is characteristic of obese people." While in Roman Galinari stressed "the so-called interruption of breathing in sleep," observed mostly in people with overweight. Today the WHO in the world numbering over 250 million obese ranging from children to adults. In America 50\% and result in overweight people. The situation is problematic in children. In France, Italy, Greece, namely 1 to 7, 1 to 4 and 1 in 5 children are obese.

From the obese physical body is distinguished by a presence of excess adipose tissue and increase the weight. Biologically obese represent a metabolic shock resulting increase in blood fats.

To turn morfologjiko - resulting in increased cell obese and increasing the lipoqelizave. In this way distorts the 
whole, obesity metabolism and physiological function of organs by providing a shock with a general character including the nervous system. Negative effects of obesity are substantial, sustained in time and hardly repairable. Materials and direct complications of obesity are:

$>$ Hiperurinemia meaning in itself increase the concentration of uric acid in the blood which is associated with major complications in all organs of the circulatory system.

$>$ Addition of free lipids in the blood as cholesterol, triglycerides, fosfolpidet of free fatty acids whose deposition in blood vessels of the heavy damages by gëlqerizuar degenerate to jam.

$>$ Increased blood glucose and the tendency toward the occurrence of diabetes kurueshëm hardly be permanent.

Unfortunately the consequences of obesity especially in children are stable and later ages in many cases exacerbated over time.

They relate to damage to the circulatory system in general and heart in particular, gjëndror system, do not capture the vital parameters of growth by age but also with other widespread damage to all vital organs including those of the central steering .Obesity itself to more of its consequences according to most scholars are responsible for the appearance of most of the several types of cancer at younger ages.

Among the causes of obesity and inheritance but some specific illnesses considered and ways of feeding: Predominant influence of nutrition has to do with the simple fact if you "know or know how to eat eat" words:

$>$ A normal amount of food which needs to meet immediate vital activity (maintenance) and increased or excessive food is constrained on these needs

$>$ A food at the proper level of protein content in fats, sugars and calories or eating too much concentrated in protein, fats, sugars and overcalory.

> A balanced diet not only the quantity of reports that mentioned the main contents and their values but also by additional factors such as vitamins, mineral salts, microelements or without food with a balance of low substantive value of the non exremity only hamper assimilation, but accompanied by adverse side effects.

A good feed is about a greater predominance of foods called "food hygiene" as cereals, meat and fresh milk and their by-products, seafood, herbs, vegetables, fruits, natural juices, etc. as away "foods antihigjenike" including readyprepared meals and semi-finished conserved through the use of salt or drying, sweets and chocolates, alcohol, various industrial fluids and in particular foods with high fat content.

Nutrition is a complex problem that concerns not only the appropriate level of knowledge and culture in this area but with a multidimensional impact including the economic one. Element is simple but strong and imposing a certain standard of nutrition in this market faced the food is the level of financial income.

Today the face of the normal trend of increasing knowledge of the whole culture of a diet as close to the Dietary natyrales other trends also show that for their own economic character appear stable. In terms of super seasonal food production arises that a large contingent of these foods undergo additional processing and other costs like packaging, packing, etc. these influential element in increasing their market price.

This first not to abuse what would be a loss for producers and a setback for the future by another provision of the food market as the best possible uniform becomes easier using the food in all possible forms. Food processing also imposed for the fact that this is the best form of conservation values off-season food products but also improve the taste of their ngrënshmërisë while food processing also makes them more comfortable in the use of processing trade in general .Today we witness the dominance of semi-finished food prepared, processed, concentrated, dried to fill the food market, refreshments character idustrial etc. which compared with the fresh foods are presented with major changes in content and value them. 


\section{Products Popular Food Chains}

Fast food (Content per piece)

\begin{tabular}{|c|c|c|c|c|}
\hline Products known chain & 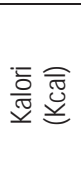 & 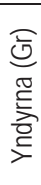 & 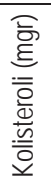 & $\frac{\bar{d}}{\bar{d}}=$ \\
\hline \begin{tabular}{|l|} 
McDonalds \\
French Fries-Medium@
\end{tabular} & 450 & 22 & 0 & 0 \\
\hline $\begin{array}{l}\text { McDonalds } \\
\text { Sandëiches Cheese burger@ }\end{array}$ & 330 & 14 & 45 & 7 \\
\hline McDonalds-Chicken McNuggets (10)@ & 510 & 33 & 85 & 0 \\
\hline Burger King & 210 & 12 & 30 & 0 \\
\hline Burger King Cheese-burger@ & 360 & 17 & 50 & 6 \\
\hline $\begin{array}{l}\text { Burger King } \\
\text { Coca Cola-Large } \odot\end{array}$ & 330 & 0 & 0 & 82 \\
\hline Burger King Hamburger $\subseteq$ & 310 & 14 & 40 & 6 \\
\hline Burger King Onion Rings, Large $\subset$ & 480 & 23 & 5 & 7 \\
\hline
\end{tabular}

Fresh food (Content per $100 \mathrm{~g}$ food)

\begin{tabular}{|l|c|c|}
\hline Food & protein & Kkal \\
\hline Veal & 20.7 & 92 \\
\hline Pork & 21.3 & 158 \\
\hline Chicken & 22.5 & 114 \\
\hline Lamb & 20.8 & 162 \\
\hline Fish & 17 & 71 \\
\hline Milk & 3.1 & 61 \\
\hline Egg & 13 & 156 \\
\hline Bread integral & 53.8 & 243 \\
\hline beans & 51 & 311 \\
\hline peas & 12.4 & 76 \\
\hline carrot & 7.9 & 33 \\
\hline potato & 18 & 35 \\
\hline Bananas & 15.5 & 66 \\
\hline juices & 14.5 & 56 \\
\hline
\end{tabular}

Another aspect is the trend to ensure a balance in the market supply quantity is a tendency towards the industrialization of production, especially in some areas as the production of meat, vegetables, corn, soybeans of GMO etccalled character. to those of this nature but with nature as cakes powerful synthetic (aspartamy) used in the food industry. In this way thanks to the intervention of human hand significantly increases the amount of their production to the detriment of quality and value, so it created a situation pashmagshme unnatural and difficult to sustain the values of foods and their use for a dietary feed.

In this respect there is a food market today in a broad range of products that the amount is considerable and meet the needs of large populations for food not particularly developed countries where food security appears less problematic, so can not mention contingents large leaf production of meat, pork, poultry, vegetables, etc. that are subject to the food processing resulting in incomplete value. Production today large quantities of maize and soybean in these ways is another factor that affects one GMO livestock products. But their byproducts arising from vetpërpunimi of maize and soybean, that not only are a wide range but also in large quantities in almost all markets and meet the nutritional needs of populations today in countries with low living standard.

This situation presents both the problematic aspects of nutrition:

$>$ First, this way it is possible to guarantee the food needs to quantify the population, and though the present data value lower if not in many cases with negative side effects.

Second, as a result of production methods in deviation from the natural to the human hand intervened strongly 
created a boom in production of GMO foods considered that for the present value on the market at favorable prices to the customer which brings the effect motion of their large consumption and consequently a significant influence on nutrition in general but the aggravation and the emergence of obesity in particular.

Obesity in children (Hopistler) is a direct result of over $90 \%$ of cases of eating too much "antihigenikc", fetched food and refreshments that in $80 \%$ of cases this condition invariably carried on throughout life with serious consequences .

His treatment of obesity is difficult and costly if you add this and curative measures for the consequences of his treatment as a whole is merely a psychological attraction of a job but also fetched a high economic cost. For the older ages is very contradictory statement to obesity, which represents the multifaceted negative influence but it remains primari accepted by most authors under which the rapid aging is closely linked to obesity, diet and movements.

An adult obese by the end of his life should be prepared psychologically, physically economics to face challenges that require patience, persistence and additional financial costs in compliance with the age level of morbidity. In conditions of market economy in general, irrespective of the nature, origin and value more and more food security as one of the primary needs of life comes rising. Even improving the quality of natural biological values of foods has the same trend due to the increasing demands for food hygiene or so-called bio foods.

For people that have positive effects these foods parameter of high biological value of food is taking more and more importance in the trend of a much better food and dietary. In developing countries interest in these foods and the need to always come to the market thanks to growing demand for raising the standard of nutrition and diet in general. For this huge investment made this a move in the right direction of the future but that in turn reflects the higher prices of these products on the market for the sake of high value and positive effects on a feed to the highest standards. In the production of organic foods very strict rules applied to create production conditions similar to those in the natural process of production of these foods.

Faced with complex nutrition situation, with many factors that go in one direction but also against each other many plan its impacts, including economic and many are of all natures, but as Professor emphasize Aleko Xoxe has an over all:

"It is the impact it normal condition of life of a child, adult or elderly person of the opposite face of the cause but as a result of eating more, when it is the result of the level of knowledge and culture in this area therefore, he says: we must learn and learn to know to eat to live, not live to eat"

\section{Conclusions}

$>$ Nutrition is a complex problem with many intertwined factors that go in one direction but also against each other.

$>$ Impacts of nutrition are multifaceted including economic.

$>$ The standard of nutrition in general and in particular it relates antiobezitet:

- With the leveling of the financial income

- With the level of food production.

> The nature of the food used by considering the relationship between food " hygienic " and "antihygienic" biological appreciation of food is one (by using as many organic foods) growing demand for food with the highest standards.

$>$ Increased knowledge of the culture of nutrition is a constant permanently raising the standard of life in general.

\section{References}

Dr.Thanos Papathanasiu,"I pahisarkia stin engjimosini ,200ktovriu 2007,gynaikologos.net-Ojinekollogos arogos tis jinekaw,07 Avgustu 2008. http://www.gynaikologos.net-paxysarkia egkymosyni.html

Idhiqi ekdhosi tu medlook.gr,"Dhiavitis se pedhja qe efivus:Simantiqi afksis llogo pahisarkias "Medlook Engjiri Pliroforisi gia tin hijia",02 Iuliu $2008 \mathrm{http}: / / \mathrm{www}$.mediook.net/eac1/diabetes.asp

Dhiqi ekdhosi tu medilook.gr,"Pahisarkia pedion qe efivon:pies i efthines ton goneon?"(“Obeziteti i fëmijëve dhe të rriturve:Cilat janë përgjegjësitë e prindërve?")Medlook Engjiri Plirofotisi gia tin hijia"(Informim i vlefshëm për shëndetin)02luliu 2008 http://www.medlook.net/eac1/parents.asr

Idhiqi ekdhosi tu medlook.gr,"Kardhiaqi prosvoli,pedhia qe pahisarkia:I epiptosis tis pahisarkias stin kardhia ton pedhion","Medlook Engjiri Pliroforisi gia tin hijia",(Botim i veçantë i medlook gr."Sëmundje kardiake,fëmijët dhe obeziteti:Ndikimi i obezitetit në zemrën e fëmijëve".Informim i vlefshëm për shendetin")02 luliu 2008 http://www.medlook.net/eac1/cancer.asp

Idhiqi ekdhosi tu medlook.gr."Karqinos,padhja qe pahisarkia:O rollo tis pahisarkias ston karqino qe pedhja"."Medlook Engjiri Pliroforisi gia tin hijia "("Botim i veçantë i medlook gr."Kanceri,fëmijët dhe obeziteti:Roli i obezitetit te kanceri dhe te fëmijët”)luliu 2008 http://www.medlook.net/cancer1.asp

Idhiqi ekdhosi tu medlook.gr,"Psili piesi logo pahisarkias sta pedhja:Apili jia tmellon tus",(Hipertoni për arsye obeziteti te fëmijët:Kërcënim 
për të ardhmen e tyre")Medlook Engjiri Pliroforisi Ogia tin hijia",02 luliu 2008 httë://www.medlook.net/eac1/piesi.as

Sintaktis tu medlook.gr,"Asbestio jia prolipsi tis pahisarkias"(Asbesti për parandalimin e obezitetit"),08 luliu 2006,Medlook Engjiri Pliroforisi gia tin hijia",02 luliu 2008 http//www.medlook.net.cy/article.asp?item id=2043

Sintaktis tu nedlook.gr,"Farmako me dhipli dhrasi kata tis pahisarkias"("Medikament me veprim të dyfishtë kundër obezitetit"),13 Martiu 2004,"Medlook Engjiri Pliroforisi jia tin hijia",02 luliu 2008 http://www.medlook.net.cy/article.asp?item id=1263

Sintaktis tu medlook.gr,"Ginidhiaki therapia enantion pahisarkia 03 lanuariu 2002,"Medlook Engjiri Pliroforisi jia tin hijia",02 Iuliu 2008 http://www.medlook.net.cy/article.asp?item id=426

Sintaktis tu medlook.gr,"Pahisarkia:Pios o rollos ton gonidhion qe tis klironomikotit Maiu 2006,"Medlook Engjiri Pliroforisi jia tin hijia", o2luliu 2008 http://www.medlook.net.cy/article.asp?ietm id=2008

Sintaktis tu medlook.gr,"Kurasi qe hiperories: Prokalun pahisarkia http://www.medlook.net.cy/article.asp?item id=1665

Sinmtikti tu Medlook,gr "Prosekste:To stress prokali pahisarkia

Fevruariu 2002,"Medlook Engjiri Pliroforisijia tin higjia",02 luliu 2008 http://www.medlook.net.cy/articke.asp?item id=774

Sintaktis tu medlook.gr, "Stirotita qe gonimotita andhron:Shesi me hipervoliko varos somatos qe pahisarkia 12 Septemvriu 2006 , "Medlook Engjiri Pliroforisi ja tin hijia",02 Iuliu 2008 http://www.medlook,net,cy/article.asp?item id=2101

Sintaktis tu medlook, "I pahisarkia vllapti sovara tnseksualiqi zoi",28 lanuariu 2005, "Medlook Engjiri Pliroforisi jia tion higjia",02 Iuliu 2008 http://medlook,net.cy/article.asp?item id=1523

Sintaktis tu medlook.gr. "Proimi jiransi llogo kapnismatos qe pahisarkias pirjes së duhanit , 15 luniu 2005, "Medlook Engjiri Pliroforisi jia tin higjia",02 luliu 2008 http://www.medlook.net.cy/article.asp?item id-11691 